Kolstø, Pål. The Sustainability and Future of Unrecognized Quasi-States. Journal of Peace Research 2006, 43(6), 723-740.

The final, definitive version of this paper has been published in Journal of Peace Research, 43/6, 2006 by SAGE Publications Ltd, All rights reserved. C SAGE Publications Ltd

http://jpr.sagepub.com/cgi/content/abstract/43/6/723

Pål Kolstø, b. 1953, professor of Russian studies, University of Oslo, Dept. of Literature, Area Studies and European Languages. Has publised extensively on ethnic conflict and nationalism in the Former Soviet and the Balkans. His monographs include Russians in the Former Soviet Republics, C.Hurst, 1995 and Political construction sites: Nation-building in Russia and the post-Soviet States. Westview press, 2000. He is also the editor of Nation-building and ethnic integration in post-Soviet societies. An investigation of Latvia and Kazakstan. Westview press 1999, National integration and violent conflict in post-Soviet societies: The cases of Estonia and Moldova, Rowman and Littlefield, 2002, Nation building and common values in Russia, Rowman and Littlefield, 2004, and Myths and Boundaries in South-Eastern Europe, C.Hurst, 2005 


\section{The Sustainability and Future of Unrecognized Quasi-}

\section{States}

Scattered around the world are a number of states and statelets that have declared independence but are not recognized by other states. These political entities are referred to by various names, 'de facto states', 'unrecognized states', 'pseudo-states' and 'quasi-states'. Since their existence is not supported by international recognition, they must be sustained by something else. In contrast to researchers who maintain that the majority of these quasi-states are quite strong, this article argues that their modal tendency is weak economy and weak state structures. The main reasons why these states nevertheless have not collapsed seem to be that they have managed to build up internal support from the local population through propaganda and identity-building; channel a disproportionately large part of their meager resources into military defense; enjoy the support of a strong patron; and in most cases have seceded from a state that is itself very weak.

None of these circumstances, however, is likely to secure the unrecognized quasistates lasting life. Unless they achieve international recognition or are united with their patron state - both of which in most cases are unlikely outcomes - they will eventually be reabsorbed into the parent state, or agree to an autonomous status within the parent state in a federal arrangement. This last outcome is the preferred option of the IC. 


\section{There are quasi-states and quasi-states}

The international system is made up of (nation)-states. Territorial-political entities such as colonies, protectorates, mandates, and other kinds of overseas territories that covered so much of the earth in earlier centuries, have for all practical purposes disappeared. Contemporary nation-states enjoy double sovereignty: internally, vis-àvis their own citizens, and externally, vis-à-vis other states. Internally, state authorities have a monopoly on collecting taxes from the inhabitants of the country, and in return provide basic services to the population such as welfare and security; externally, they are recognized as the sole representative of the nation in international fora.

However, also two types of territorial-political entities do not fit this basic description of the nation-state in today's world. Some would-be states lack internal sovereignty: in these cases the state authorities, while internationally recognized as the sole representative of the state, nevertheless fail to fulfill the basic tasks required of them with regard to provision of services to and protection of their citizens. In other cases, the state as such is not accepted by the international community as legitimate. This denial is not based on any assessment of their internal sovereignty, which may or may not be deficient. The reason instead is that the would-be state has seceded from a recognized state that does not accept this loss of territory. Such secessionist states can be said to lack external sovereignty.

It is immediately clear that in important respects these two deviations from the normal nation-state model are very different, indeed, diametrically opposite. Even so, these two phenomena are often described with the same appellation: Quasi-states. Such 
terminological confusion is clearly undesirable and ought to be eliminated. In this article, however, I will make use of the terminological coincidence to highlight the particularity of unrecognized quasi-states by pointing out the similarities and differences with the other type of quasi-states.

For quasi-states without internal sovereignty international recognition is enough to survive. The sanctions against encroachment on the territorial integrity of all recognized states are so powerful that even the weakest are guaranteed a continued life. In the anarchic international system states play hardball for power and influence but they do not try to eliminate each other. Iraq's botched attempt to gobble up Kuwait in 1990 is just the example that proves the rule.

But this begs the question: if international recognition is the magic trick that keeps weak states from sinking into non-existence in the modern world, how can unrecognized quasi-states exist without it? As we shall see, the answer cannot be state strength since many of these unrecognized quasi-states are in fact quite weak by any standard. Even so, they are not only still with us, but their numbers have in fact proliferated over the last decades.

\section{Quasi-states as states with external sovereignty only}

In his seminal book Quasi-states: Sovereignty, International Relations and the Third World Robert H. Jackson pointed out that most European colonies in Africa that achieved independence in the 1950s and 1960s were ill prepared for sovereign statehood (Jackson, 1993). They had been ruled like British counties or French départements, and lacked even the most basic infrastructure of government. They had 
no elites with sufficient professional training and social responsibility to take over the reins of the state.

In the past states were created through war and diplomacy, and states that could not fend for themselves disintegrated and disappeared from the map. The postcolonial states, however, continue to exist even in the absence of the basic qualities that in the past were deemed indispensable for statehood. The post-Word-War II state system extends recognition to states on a purely formal basis. The result has been the emergence of a qualitatively new type of state: the quasi-state, Jackson claimed. Quasi-states are kept from collapsing by leaning on an external scaffolding of international recognition, not by any internal structure of institutions and laws. Being protected by international law against external intrusions, quasi-states possess only external or negative sovereignty.

State leaders in quasi-states often receive the bulk of their revenues not from the taxing of their own population but from international donors and through the exploitation of the country's exportable natural resources. Most of the money finds its way into the pockets of the power holders, and is not invested in projects to strengthen the state or improve conditions for the population. The relationship of the 'state' to its population is therefore extremely tenuous. The leaders of the quasi-state do not depend on support from below in order to survive in office. Instead, competing elites vie with each other for control of the 'state' — or rather for the right to present themselves abroad as the representatives of this virtually non-existent entity, since this badge carries with it the possibility of manipulating external donors and extracting internal resources. 
Jackson's book triggered a wide debate on the nature of post-colonial states. He has been criticized for tarring all third world countries with the same brush (see e.g. Haynes 1994) and clearly, there are vast differences in state capacity and state structure between, say, Liberia and Botswana. Even so, Jackson alerted us to an important and serious problem in international relations. While his book was highly influential, however, his key terminology nevertheless failed to establish itself. It is still being used in specialized academic literature, but in journalism and political jargon other terms are used to describe the same or virtually the same phenomena as what Jackson referred to as quasi-states. Most commonly used is 'failed states' ${ }^{1}$ while some authors write about 'weak states' and 'shadow states' to describe states that lack internal sovereignty (e.g. Beissinger and Young, 2002).

At the same time, we can note that the term 'quasi-state' is increasingly used about the opposite phenomenon of less-than-real statehood: about states that lack international recognition. Gail Lapidus, for instance, writes that politically and militarily frozen conflicts in post-Soviet Eurasia 'have resulted in the creation of several quasi-states [that have] de facto control over their own territory but are unlikely to be recognized by the international community' (Lapidus, 2002). Numerous other examples of a similar use of the term could be cited (Baev 1998; Holmes, 2001; Bridge, 2004; Cornell, 2003).

To be sure, 'quasi-states' is not the only term used about states that wish for but are denied a seat in the UN General Assembly. Scott Pegg and Dov Lynch prefer the term de jure state, while Charles King calls them 'unrecognized states’ (Pegg, 1998; 
Lynch, 2002; King, 2001). ${ }^{2}$ Both of these terms highlight important qualities of these 'almost-states'. ${ }^{3}$ When I in this article nevertheless stick to the term 'quasi-states' it is in order to underscore the similarities between the two types of quasi-states, those lacking internal sovereignty and those lacking international recognition. Both categories are located at the margins of the international system of states and challenge basic assumptions of this system. Furthermore, they are quite often found on the same territory and relate to each other as cause and effect: A Jacksonian-type quasi-state is often too weak to control effectively all of its territory, and this makes it possible for political elites on the periphery to break away from state authority and proclaim their region an independent, but unrecognized state. Entities of both kinds tend to be hot-spots in international politics: they are products of warfare as well as causes for new armed conflicts. And finally, there are strong reasons to believe that if any of the unrecognized quasi-states of today's world should succeed in achieving international recognition most of them will end up not as 'normal' or full-fledged states but instead transmute into recognized quasi-states of the Jacksonian variety.

Below, the term 'quasi-states' will be reserved for states that have proclaimed independence but lack international recognition. Whenever there is a need to refer to quasi-states of the opposite kind, they will be labeled 'Jacksonian quasi-states' or 'failed states.'

\section{Quasi-States-a brief survey}

Unrecognized quasi-states are found on several continents-Europe, Africa, and Asia-but they are not evenly distributed over the surface of the globe. After the end of the Cold War there has clearly been a higher than average incidence of such 
entities in the former Soviet Union and in the former Yugoslavia - that is, in two recently disintegrated multinational communist federations. In the former Soviet republic of Moldova we find the Dniester Moldovan Republic (DMR); in southern Russia, Chechnya; and in Azerbaijan, the Nagorno-Karabakh Republic. Georgia has the dubious distinction of being the home of two quasi-states: Abkhazia and South Ossetia.

In former Yugoslavia, Kosovo in many respects approaches the status of a quasi-state. Republika Srpska in Bosnia had that status until it was recognized as an entity within Bosnia-Herzegovina after the signing of the Dayton agreement in 1995. In the same year also another entity could be removed from the inventory of quasi-states in the former Yugoslavia when Republika Srpska Krajina in eastern Croatia was overrun by Croatian forces under Operation Storm.

On the border between Europe and Asia there is, in addition to Chechnya, also the Turkish Republic of Northern Cyprus (TRNC). Between the first and the second Gulf War the Kurdish-controlled areas in Northern Iraq basically conformed to a quasistate status. Africa has had at least four quasi-states since decolonization, one of which (Eritrea) has achieved international recognition, while two (Katanga and Biafra) have been eliminated, and one (Somaliland) continues as an unrecognized entity. In Sri Lanka we find another such state, Tamil Eelam, proclaimed by the LTTE (The 'Tamil Tigers') in 1977. Taiwan, recognized by twenty-eight countries, can be said to be in a category of its own and occupy an intermediate position between a recognized state and a quasi-state. 
As this list of defunct and extant quasi-states shows, these entities lead a highly precarious existence. They come and go, but some have displayed considerable staying power - the oldest among them today, the TRNC, was established in 1974, and has thus existed continuously for an entire generation. Of the quasi-states established on the territory of the former Soviet Union after the fall of communism, all except Chechnya continue to muddle through.

Considering the strong bias against quasi-states in the international state system, what we need to explain is not so much the reasons for the demise of some of these stateswhich is the expected outcome-but the tenacious persistence of some of them.

\section{Previous research}

Little attention has been paid to unrecognized quasi-states. My attempt to find theoretical or comparative literature on these unruly political creatures yielded a meager catch. Only one monograph and a smattering of specialized articles deal with unrecognized quasi-states in a comparative or theoretical perspective. Among them, Scott Pegg in his otherwise quite comprehensive study International Society and the de Facto State (1998) virtually ignores the post-Soviet space, while articles by Vladimir Kolossov and John O'Loughlin, Charles King and Dov Lynch focus almost exclusively on quasi-states in the post-Soviet space. This geographical difference in their scholarly attention often lead them towards diverging conclusions, but on one crucial point all but one of them agree: Unrecognized quasi-states are remarkably robust, state-like entities. 
Scott Pegg argues that 'A de facto state (= unrecognized quasi-state) requires some sort of viable, organized, functioning governing entity. The mere fact that a sovereign state's control does not run throughout its entire country should in no way be interpreted as indicating the presence of a de facto state' (Pegg, 1998, p. 28). Even so, in his overview of potential de facto states Pegg includes, with some reservations, virtually all of the quasi-states listed above.

Charles King for his part regards most of the quasi-states on the territory of the former Soviet Union as 'surprisingly strong'. 'The territorial separatists of the 1990s have become state builders in the early 2000 s, creating de facto countries whose ability to field armies, control their own territory, educate their children, and maintain local economies is about as well developed as that of the recognized states of which they are still notionally a part' (King, 2001, p. 525). This ability of post-Soviet ethnic separatists to build reasonably well-functioning states King sees at a crucial reason behind their survival.

In contrast to these views Dov Lynch sees the de facto states as failing. 'They have the institutional fixtures of statehood, but they are not able to provide for its substance' (Lynch, 2002, p. 841). Charles Fairbanks shares this view and expresses the failure of quasi-states in ever stronger terms as 'the weakest of weak' (Fairbanks, 2002, p. 141).

Evaluations of strength and weakness are inevitably relative and the concepts of 'state strength and 'state weakness' must be defined in order to be operationalized. A working definition of strong states is provided by Ghia Nodia as 'states that are capable of carrying out functions that they themselves claim and that they are 
reasonably expected by their populations to carry out' (Nodia, 2002, p. 415). Building on Nodia's definition Crawford Young defines the opposite phenomenon of a 'weak state' as a state that 'meets minimum Weberian definitions of institutions of rule and is able to carry out some basic functions but is far from performing according to domestic and international expectations of a "normal" state' (Young, 2002, p. 446).

Basing myself on these definitions, I agree with Lynch against Pegg, King, and Kolossov \& O'Loughlin. I will argue that the modal tendency of quasi-states is deficient state-building. Furthermore, as I explain below, there are strong structural reasons why this should be the case. Perhaps only a few quasi-states may be counted among 'the weakest of the weak', as Fairbanks calls them, but in hardly any of them is it successful state-building that keeps them from collapsing. This means that we must looks elsewhere for an answer to my initial question: what is it that sustains quasistates?

\section{Undermining Sustainability by Deficient State-Building and a Criminalized}

\section{Economy}

A few quasi-states operate reasonably well. Apart from the extreme success story of Taiwan, which is an anomalous case, we have for instance the relatively wellfunctioning Turkic Republic on Northern Cyprus. But also TRNC has serious economic problems, and Greek Cypriots have a per capita income that is three to four times as high as that of the citizens of TRNC.

Some quasi-states have been given rather conflicting assessments. Somaliland has been characterized both as a 'comparatively strong democratic credentials and 
functional effectiveness' (Pegg, 1998, p. 11), and 'a pirate state based on criminalterrorist activities' (Kolossov and O'Loughlin, 1999, p. 155). Also with regard to DMR opinions vary widely. Vladimir Kolossov and John O’Loughlin claim that 'Eight years after the declaration of sovereignty, [DMR] has all the attributes of a normal state, except for international recognition. These include a constitution adopted by referendum, an elected parliament and president, formal government, a system of security (police, an army of 5,000 to 7,000 men, and customs services), a system of elected local administration, and a (weak) currency' (Kolossov and O’Loughlin, 1999, p. 167). Other observers, however, point out that the Dniester republic has a thoroughly criminalized economy, based on smuggling and fake brand industry. The republic has also been accused of being a free haven for fugitive gangsters and former KGB officials in hiding (see King, 2001; Duplain, 1994, 13).

State weakness may be the result of deficient capabilities or deficient will. The economic resources of most quasi-states are clearly small. Kosovo was the poorest region in Tito's Yugoslavia, and Chechnya, Nagorno-Karabakh, and South Ossetia were all very backward regions in the Soviet Union. The situation of Abkhazia and the DMR is different. In the Soviet period, both of these regions fared better than most other parts of their respective parent republics, Georgia and Moldova. Srpska Krajina occupied an intermediate position: It included both very backward regions, in Krajina proper, as well as some rather well-to-do, oil-rich regions in eastern Slavonia. In Africa, Biafra was a resource-rich region that failed to establish itself as an independent state - in spite of substantial Western sympathy - while poverty-stricken and unknown Somaliland still has not been reunited with its challenger state, Somalia. 
At the same time, state weakness is often a result of policy rather than fate. Leaders of Jacksonian-type quasi-states lack incentives for effective state-building since they can achieve power as well as personal wealth without it. William Reno claims that, in extreme cases, leaders of failed states — or 'shadow states,' as he calls them - may have a positive incentive to destroy remaining formal institutions. 'Rulers who do not offer postal services jealously guard the unfulfilled prerogatives of state sovereignty' (Reno, 2002, p. 110).

Most unrecognized quasi-states have certainly not stooped to the level of shadow states, but some like Chechnya, come unnervingly close. Valery Tishkov describes Chechnya between the first and the second Chechen Wars as a society on the brink of complete anarchy. The state institutions were pure fiction, communications were erratic at best, schools were closed, stores empty, and production had ground to a halt. The only thriving businesses were smuggling, looting, and hostage taking. People were killed for a trifle, or for no reason at all, and there was no-one to deter the perpetrators. The warlords knew no solidarity, not even towards their own clan (Tishkov, 2004).

Chechnya may be an extreme case and Tishkov's picture may be painted in excessively dark colors. Even so, reports from other quasi-states are often almost as bleak. In Abkhazia, Dov Lynch reports, the government 'maintains the daily operations of legislative, executive and judicial institutions, but performs very few services for the population.... Moreover the state is unable to provide for law and order across its claimed territory' (Lynch, 2002, 836). In NKR the inhabitants eke out a living by smuggling, drug traffic, and selling timber to Iran and other countries. 
Living conditions in South Ossetia are just as bad, if not worse. Kosovo has been characterized as a place with 'no rule of law, no ethnic tolerance, no human rights. Not even an economy, except foreign aid and organized crime' Pascali, 2001).

There are several reasons why quasi-states fail to develop well-ordered economies. One is war damage. Secession has normally been won through a civil war that was fought mostly or entirely on the territory of the quasi-state. The length and ferocity of these wars have varied, but often they led to the destruction of entire villages and even towns. Another reason is what Scott Pegg has called 'the economic cost of nonrecognition' (Pegg, 1998, 43). Foreign firms are wary of investing in a quasi-state since legal contracts might not be internationally binding there. Investors may also be afraid of offending the parent state, lest they be barred from trade with its normally larger market. In some cases - Cyprus is a case in point - the parent state has also been able to impose a successful international embargo on the secessionist territory.

While a status as quasi-states puts a damper on normal legal trade with the outside world it encourages illegal business. As already indicated, virtually all quasi-states have a large shadow economy, often with intimate links to top state leaders. Local officials and authorities profit from this business through cuts and kickbacks, but the quasi-state as such derives no benefit from it. The 'revenue' collected in this way goes into private pockets and not to the state exchequer. While this phenomenon is of course well known from other countries, and in the Western world as well, certain circumstances conspire to aggravate the problem in quasi-states. One is the civil war which in most cases preceded the establishment of the quasi-state. In times of war, not only buildings are destroyed, but also civil and legal structures are disrupted and 
illegal activities easily go unchecked. As Espen Barth Eide has remarked with regard to Kosovo, 'While wars, blockades and exceptional situations are devastating for the majority, they create breeding ground for certain types of economic activity that proves particularly effective in the absence of order. The people that benefit from such activities see few reasons to support the re-establishment of effective public control' (Eide, 1999).

If the war experience were the only problem, it would conceivably be gradually diminished after peace, but also certain qualities inherent in quasi-states are conducive to a criminalization of the economy, irrespective of the war factor. Since these states are not recognized, no international conventions can be applied, and no effective monitoring by international organizations is possible. The resulting lack of transparency in these states is extremely attractive for criminal and other shady businesses. As Thomas de Waal has argued with regard to the quasi-state he has studied, ‘... internationally, Nagorny Karabakh remained as much an outlaw as Chechnya. None of its laws or institutions were valid outside its own borders, and no foreign diplomats, apart from peace negotiators, set foot there. That was virtually an invitation to become a rogue state' (de Waal, 2003, p. 246; see also Cornell, 2003, 218).

\section{Circumstances sustaining quasi-states}

Most quasi-states then, lack not only international recognition both also strong state structures, and still they exist. At least five factors can be identified that contribute to the viability of unrecognized quasi-states: Symbolic nation-building; militarization of 
society; the weakness of the parent state; support from an external patron; and lack of involvement on the part of the international community. The sections below present these factors separately and then discuss how alterations in the character and the relative weight of each of them may lead to different ends to quasi-states.

\section{NATION-BUILDING}

A distinction can be made between state-building and nation-building. State-building as discussed above pertains to the institutional, economic, and military groundwork of functional states, the 'hard' aspects of state construction, as it were. Nation-building, on the other hand, concerns the 'soft' aspects of state consolidation, such as the development of a common national identity among the inhabitants through symbols, propaganda, history writing and the cultivation and 'invention' of traditions and national customs. 'Nationhood' and 'national identity' are not inherent qualities of a state's population, but is developed and sustained through nation-building.

All nations in today's world are proclaimed as nation-states. Rightly or wrongly, state leaders invariably claim to represent their 'nation'. In a similar way the leaders of quasi-states speak on behalf of the Ossetian people, the Somaliland people, the people of Dniestria, and so on. Like other states, they strenuously try to foster a sense of common identity and destiny among the inhabitants of the territory they control. Through nation-building the quasi-state leaders seek to muster backing from within, from the local population, to create or prop up its internal sovereignty.

Normally, successful nation-building to a large degree depends upon successful statebuilding. Through nation-building, the state authorities are, as it were, asking the 
population to attach their allegiance to this particular state by identifying with it. Before the citizens decide to do so, they are prone to ask, 'What do I get in return?' The standard answer to that question is 'security and welfare services'. A state that cannot deliver the basic services expected of it will find it much harder to win the loyalty of its denizens than a state that can. Even so, I will argue that even in the absence of effective state-building most quasi-states have succeeded reasonably well in their nation-building efforts. The available evidence suggests that the population of most quasi-states share a high degree of common identity as a nation. There are mainly three reasons for this.

Firstly, quasi-state nation-builders can draw upon the memory of the civil war through which the quasi-state was established. The fact that all quasi-states - by continuing to exist - can claim to have won the civil war increases the possibilities of exploiting war memories for nation-building purposes. This is done in many different ways. War memorials are constructed and Days of victory and Days of mourning are instituted. DMR has published a number of booklets and brochures on the 1992 war, including a memorial book with pictures and names of all 457 Dniestrians who died (Kniga pamiati, 1995). Nagorno-Karabakh and other quasi-states have instituted a series of medals and orders for valor and service to the Fatherland. Some of the medals have been awarded posthumously to martyred soldiers (Orders and Medals, 2005).

Secondly, quasi-states authorities can cultivate the image of the Common External Enemy. Even if the civil war is a thing of the past, the challenger state - the parent state-continues to exist and to claim jurisdiction over the breakaway region. Like other states, many quasi-states are riven by strong regional, ideological, and other 
divisions but the image of the Common External Enemy serves as a powerful motor for national unification. In this way the challenger states in spite of themselves contribute to the consolidation of nations they deny the existence of. ${ }^{4}$

Finally, the population of the quasi-state has been homogenized through population exchanges and ethnic cleansing that preceded or accompanied the secession. The part of the population that sympathized with the parent state for ideological reasons or identified with it on ethnic grounds has in many cases been induced to flee, often with quite coercive methods. Conversely, many supporters of the secessionist cause who formerly lived outside the breakaway region, will have taken up residence in the unrecognized quasi-state. Also this reverse population movement is often the result of forced expulsions. In this way Nagorno-Karabakh was cleansed of virtually its entire Azeri population in 1988-91, while ethnic Armenians living in other parts of Azerbaijan fled to Armenia en masse. Prior to the 1974 war Turkish-Cypriots had been living scattered around the entire island of Cyprus, while the territory of what is now TRNC had a Greek-Cypriot majority. The present population pattern, then, with a virtually 100 percent Turkish-populated Northern Cyprus, has been achieved through fear-induced flights in both directions.

In 1989 ethnic Georgians made up 45 percent of Abkhazia's population while ethnic Abkhazians constituted only 18 percent, but during the 1993 war most ethnic Georgians fled to Georgia proper. This was not an accidental side-effect of the hostilities, but the result of a deliberate policy to undo the consequences of what the Abkhazian leaders see as an intentional change in the ethnic structure of Abkhazia in 
the Soviet period: in the early $20^{\text {th }}$ century ethnic Abkhazians had constituted a majority population in Abkhazia, and this situation they were determined to recreate.

In some instances, with DMR as the best example, a separate identity for the population of the rebellious region has been achieved without any ethnic cleansing. Ethnic Moldovans make up roughly 40 percent of DMR's population, and while many of them sympathize with the Chisinau regime quite a few clearly share in the common supraethnic Dniester identity fostered by the Tiraspol leadership. This identity is based not on ethnicity, but on a common language--Russian, a separate history, and a certain Soviet nostalgia (Kolstø and Andrei Malgin, 1998).

All quasi-states have adopted a state flag, a national anthem, a state coat of arms, new national holidays, and other symbolic attributes of statehood. They also build museums, erect statues, rename streets, and frequently create a cult of personality around their leader in order to inculcate in the population a sense of common past and common allegiance to the same state (Troebst, 2003). All states, both old and new, engage in such symbolic nation-building, but for newly established states-quasistates as well as recognized states - such endeavors are particularly important. The more tenuous the claim to separate nationhood, the more effort and ingenuity the state authorities need to employ to convince the population of its reality (Kolstø, 2000).

There are no objective criteria by which one may assess to what degree the nationbuilding of quasi-states is a success or failure. Many quasi-states have an authoritarian regime in which election results must be treated with great care as indicators of popular attitudes. Through various methods, however, popular support for the quasi- 
state's statehood may nevertheless be gauged. An opinion poll in DMR in 1998 showed that residents in the Tiraspol-controlled region of Moldova did indeed dissociate themselves from the Moldovan nation-building project and to a large degree identified with the DMR state (Kolst $\varnothing, 2002$, pp. 31-70). Such data, however, will always be subject to interpretation and those who dispute them may claim that the respondents have been coerced by local authorities or manipulated by secessionist propaganda. (I note, however, that if people support the state as a result of propaganda this simply means that nation-building efforts are bearing fruit - that the propaganda is effective.)

\section{MILITARY POWER}

'Soft power' in the shape of internal support from the population, however, is not enough to secure quasi-states continued existence. The quasi-state was created by military means and must be maintained by the same means. As political entities that are not protected by the international system of mutual recognition they are thrown back into the Hobbesian jungle and more than other states they must rely on brute force in order to survive. Their armed forces, however, do not have to be very large. Charles King has estimated the armed forces of the quasi-states of the former Soviet Union to be 15,000 to 20,000 thousand in Nagorno-Karabakh, 5,000 to 10,000 in DMR; 2,000 in South Ossetia, and 5,000 in Abkhazia (King, 2001, 535) Compared to the size of the national army in most states, it is not very much, but relative to the size of the total population in the statelet this is considerable.

For the quasi-states the need for a strong military capability means that they must devote a disproportionately large part of the resources of the state to defense purposes. 
This leaves fewer resources to civilian purposes, and contributes to the weak development of welfare, educational facilities, and the building of infrastructure in the quasi-states. Even if the authorities in quasi-states should have the will to develop strong civilian state structures - and as argued above in many cases there is reason to suspect that this will is quite weak - they would normally not have the capacity for it.

The crucial role of the armed forces for the survival of the quasi-states further leads to a militarization of society. The constant reminder of the civil war underscores the vital role of the armed forces for the survival of the country, and props up the prestige and influence of the military establishment in the statelet. In many quasi-states military leaders have also been able to transform this influence into political and economic power. In Kosovo former KLA officers today control shady business structures as well as local political bodies (Pascali, 2001). Another example is PMR. For many years the strongman of PMR was the interior minister Vadim Shevtsov, alias Antiuf'ev, a former KGB general who is wanted in Latvia for his activities during Latvia's liberation struggle (Bowers, 1994, p. 562). In NKR a certain Samvel Babayan made a name for himself during the war with Azerbaijan and was skyrocketed into the position of Minister of Defense. That position he used to line his pockets and terrorize the local population until he fell out with the president of the quasi-state and was arrested in March 2000 (de Waal, 2003, pp. 241-43).

\section{THE WEAKNESS OF THE PARENT STATE}

Military strength and military weakness are of course relative measures. It is enough for the quasi-state to be sufficiently strong to keep at bay the parent state from which it has seceded. And in fact, the parent state of most quasi-states is a weak state, in 
political and institutional as well as in military terms. This is the most important reason why we find a particularly high concentration of unrecognized quasi-states in the former Soviet Union and former Yugoslavia. At the time when they were established amid the ruins of these two communist federations they were extremely weak, in the grips of a painful political and economic transition. This created a window of opportunity which secessionist groups in several states availed themselves of.

Georgia, Azerbaijan, and Moldova were not only economically and politically weak in the first years after independence, but also riven by severe internal conflicts. Moldovans were deeply divided on the issue of unification with Romania, while Azerbaijan went through several coup d'etats and regime changes before Geidar Aliev managed to install himself, and later his son, in power. Georgia fared worst of all, as the country in 1992 descended into a civil war in which Georgians confronted Georgians, a war that ran partly parallel with the military campaigns against the separatists. In the early to mid-1990s Georgia clearly qualified as 'failed state' (Nodia, 2002).

To be sure, not all Soviet successor states were equally weak. The largest by far, Russia, was clearly in a much better position to defend its territory, although the economic transition hit also this country hard. Russia could take over the organs of administration of the central Soviet state, as well as the lion's share of the former Soviet Army units and their equipment. Still, even Russia has not been able to establish full control over all parts of its breakaway region, Chechnya. 
The weakness of the parent state was a major factor behind also the establishment of African quasi-states. Like the Soviet quasi-states, Katanga was proclaimed when its parent state, Congo, had just been established. The former colonial power, Belgium, was notorious for its failure to build up any infrastructure or state apparatus, or to provide for the education of an indigenous elite capable of taking over after independence. The two parent states on Africa's Horn are likewise extremely weak. Somalia was and still is a paradigmatic case of a failed state, with no functioning state authorities, while Ethiopia in 1991was defeated on the battlefield by the Eritrean separatists.

As long as the parent state is mired in political chaos and economic misery it is not only prevented from launching a new war to recapture the lost territory but also fails to attract the population of the breakaway region. Even those citizens of the quasistate who are thoroughly disgusted with their self-proclaimed leaders have few reasons to wish for reunification with a scruffy parent state.

\section{EXTERNAL PATRON}

However, not all parent states are as weak as the ones described above. Some quasistates must defend themselves against states with a well-functioning state apparatus, a solid economy, and good defense capabilities. Most quasi-states, even those that face weak parent states, are therefore dependent upon support from an external patron. Such a patron may be said to fulfill the same role as the international community does vis-à-vis recognized Jacksonian quasi-states or failed states. In such cases the role of the international society as guarantor of continued existence for weak states has been privatized, as it were. 
With a powerful patron, a quasi-state may be able to hold out even against a relatively strong challenger state. Taiwan is a strong state for its size, not only economically, but also militarily. Like most other quasi-states Taiwan, or Formosa, was established when the parent state, the People's Republic of China, was weak, torn apart by a protracted civil war. Today, however, China is a formidable military power that could (and no doubt would) overrun Taiwan were it not for Taiwan's external patron, the United States.

The Dniester Republic, Ossetia, and Abkhazia enjoy the support of Russia while Northern Cyprus has another powerful patron, Turkey. In the post-Soviet cases, this patronage is unofficial: Russia has not recognized any of its client states, but without the involvement of the Russian Fourteenth Army in the Moldovan civil war in 1992, the Dniester statelet would most probably have disappeared from the map (Neukirch, 2002). Also in the wars in South Ossetia and Abkhazia the Russian military played a crucial role. In the case of the Turkish Republic of Northern Cyprus the patronage has been quite open and explicit: Turkey has, as the only country in the world, extended official recognition to its Cypriot daughter republic and also supplies most of its military defense.

A major reason why Republika Srpska Krajina and Republika Srpska in Bosnia managed to break away from Croatia and Bosnia, respectively, was surreptitious military support from the Yugoslav army and Serbian authorities. Armenia, the patron state of Nagorno-Karabakh, is itself a weak state with a tottering economy. Even so, it is the life-line to Armenia that keeps Nagorno-Karabakh ticking. A clear illustration 
of the intimate links between the two states is the fact that the current president of Armenia, Robert Kocharian, hails from Nagorno-Karabakh and has previously been its president. Every year Armenia provides NKR with an interstate loan that covers 75-80 percent of its budget (Lynch, 2002, 847). Nonetheless, Armenia has not officially recognized the political independence of Nagorno-Karabakh.

Some observers surmise that the quasi-states serve as political instruments which the patron states use to put pressure on the parent states and generally to project power into the region. No doubt patron states often do have such designs, but experience has time and again shown that most quasi-states are not pliant clients doing their master's bidding. The leadership of DMR, for instance, openly supported the political enemies of president Yeltsin during the 1993 power struggle in Moscow (Socor, 1993). Quasistates have agendas of their own and have occasionally even been able to wag the dog, as when NKR in 1998 was instrumental in toppling president Levon TerPetrossian in Armenia, whom they regarded as too accommodating towards Azerbaijani demands (de Waal, 2003, pp. 256-61). Even so, for most quasi-states the support from an external patron is crucially important and their survival chances would be drastically reduced should it be withdrawn.

\section{THE ROLE OF THE INTERNATIONAL COMMUNITY}

The international community, (IC) has played several roles in the conflicts between quasi-states and their parent states. By denying the quasi-states entrance into the international state system it has frustrated their aspirations to graduate into 'real' statehood. At the same time, the IC in a few instances has functioned as a collective external patron of a quasi-state. Finally, it has engaged in negotiations and 
peacekeeping missions in quasi-state conflicts. While the IC as such is clearly in favor of peaceful, negotiated settlements to these conflicts, it seems fair to conclude that its involvement in most instances has had a quite different effect, and inadvertently contributed to the prolonged existence of the quasi-states.

The two cases where the IC may be said to have functioned as the external patron of a quasi-state are Kosovo and the Kurdish-controlled territories in Northern Iraq between the first and second Gulf wars. The degree of active involvement in these cases differs. In Northern Iraq it was a matter of denying the parent state the possibility of recapturing control of the area while leaving administration in the hands of the local population. In Kosovo, by contrast, the United Nations and NATO through KFOR and UNMIK have virtually taken over the military defense as well as direct oversight of the civilian administration. Kosovo is today for all practical purposes run as an international protectorate.

More commonly, the IC has engaged in quasi-state conflicts by offering its good services as facilitator and arbiter at the negotiating table. Typical cases are the OCSEsponsored negotiations in the DMR conflict, the so-called Minsk process to resolve the Nagorno-Karabakh conflict-also OCSE-sponsored, and the UN-facilitated negotiations for Cyprus. Sometimes such negotiation efforts have been accompanied by a deployment of peace-keeping forces.

The problem with the involvement of the IC in quasi-state conflicts is the indecision and inconsistency it has been pursued with. The lack of vigor and determination in these efforts clearly reflects the low priority these conflicts have in Western capitals. 
This has made it possible for regional actors with a stronger interest in the conflict to interfere in the process and pursue their own agendas. This happened for instance when Russia - a member of the Minsk group - in 1994 launched its own parallel initiative in the Nagorno-Karabakh conflict, highjacked the negotiations, and imposed a lasting ceasefire - but no peace - on its own terms (de Waal, 2003, pp. 237-40; Baev, 1998).

Rather than resolve conflicts stalled negotiations freeze them and perpetuate status quo. In this way, they contribute to the prolonged existence of the quasi-states. The same may be said about most peace-keeping missions. The party most likely to renew hostilities in these conflicts is the parent state since it wants to regain lost territory, while the unrecognized quasi-state is normally satisfied with holding on the territory it has control over. For these reasons, the international peace-keepers deployed between the warring parties for all practical purposes function as additional border guard units for the quasi-state, behind which it may pursue its nation-building and other activities.

\section{Possible ends to quasi-states}

The combination of factors identified in the article-nation-building, military power, the weakness of the parent state, support from an external patron, and the tepid engagement of the IC-have secured some quasi-states an impressive longevity. Even so, they are regarded as essentially transient phenomena, and it is generally expected that they will sooner or later disappear as such. Theoretically, this may happen in one of four ways: they may be included into the external patron state; be reabsorbed into 
the parent state; unite with the parent state in a federal arrangement; or achieve international recognition as an independent state.

The likelihood that one or another of the four outcomes will come to pass will increase or decrease with changes in the political climate and also to a large extent depends upon shifts and developments in the factors that now sustain the quasi-states. Thus, for instance, a quasi-state may increase its chances for achieving political recognition if it manages to build strong state structures and liquidate the most blatant criminal activities on its territory. Conversely, a parent state may be able to reabsorb the secessionist territory by force if it manages to muster a strong army, or by peaceful means if it succeeds in building effective state structures and a better economy than the quasi-state, thus holding out a promise of a higher standard of living for the quasi-state population in case of reunification.

The chances for negotiated federal settlements will improve should the international society decide to play a more active role in any of these conflicts, especially if the involvement is backed with credible threats of economic and/or military sanctions against non-compliant parties. The likelihood of this outcome will increase further if the external patron is persuaded to drop or reduce its patronage of the quasi-state.

Any settlement of any quasi-state conflict will have repercussions into the remaining unresolved cases. If a parent state manages to regain control over a lost territory with military means, this will obviously encourage other state leaders to try the same solution. Conversely, the granting of international recognition to one quasi-state, even 
if presented as an 'exceptional case', will embolden other quasi-state leaders and make them even less amenable to compromise solutions than before.

Below, these four possible scenarios will be discussed in the order in which they, in my judgment, represent probable outcomes to these conflicts.

\section{INCLUSION INTO THE EXTERNAL PATRON STATE}

While political leaders in both Nagorno-Karabakh and Northern Cyprus, as well as in their respective patron states, aver that unification is not what they are aiming for, it seems reasonably clear that for these quasi-state leaders this represents the optimal solution. The inhabitants of Abkhazia and South Ossetia already enjoy a special visa regime with Russia not granted to citizens of their parent state, Georgia, and for political leaders in South Ossetia inclusion into the Russian Federation is obviously what they hope for. Certain groups also in the DMR are pushing for unification with Russia, even if this quasi-state does not have a common border with Russia. They point to the Kaliningrad oblast as a precedent for such exclave status, ${ }^{5}$ but this argument is not likely to receive wide support, either in Russia or in the Western world. So far there are no examples of successful inclusion into the external patron state, unless we count Nagorno-Karabakh as such a case. The fact that even in Nagorno-Karabakh the de facto inclusion is not officially acknowledged is an indication of the weak support this solution enjoys internationally. The NKR will not have any demonstration effect on other cases.

\section{FULL INDEPENDENCE}


Full independence and international recognition clearly remain the ultimate goal for most secessionist groups. However, in the post-World War II period, the unwritten rules of international relations have contained extremely strong restrictions against the creation of new states (Österud, 1997). While the principle of the self-determination of peoples is enshrined in the UN Charter, this right is interpreted as pertaining to the entire population of a state only, not to any of its territorial or cultural subgroups. It gives the citizens a right to elect their own state leaders, but not to opt out of the state altogether. The community of recognized states has thus in principle been closed on both ends. While no members are thrown out, the entrance gate has been strictly guarded and new applicants are routinely turned away.

To be sure, this restrictive policy has not prevented a veritable explosion of the membership of the United Nations - from the original fifty-one signatory states to its present 191 members. Most of the new entrants were admitted in one of two periods: Between the mid-1950s and mid-1960s a host of former colonies in Africa and Asia were granted membership in the UN, and in the 1990s the same happened to former republics of the three dissolved communist federations in Europe and Central Asia.

All fifteen republics in the USSR had a constitutional right to secede, and in 1991 the Soviet republics were only exercising a right granted to them by the communist leaders themselves, it was argued. In addition, the dissolution was basically peaceful: even if the Soviet leadership under Mikhail Gorbachev opposed state dissolution, the Soviet republics granted each other mutual recognition. In the Yugoslav case the argument was slightly different. In the summer of 1992 the Badinter Arbitration Commission presented a report that concluded that the Yugoslav state was already 'in 
the process of dissolution' (Welhengama, 2000, p. 250). This view was accepted by the EU and the UN, and on that basis the former Yugoslav republics were recognized one by one.

Today's quasi-state leaders draw parallels to both these periods of state creation in order to justify their cause. Depending on the circumstances, they present their independence struggle as one of decolonization and/or decommunization (See 'Chechens Appeal', 2001, and Nagorno Karabagh, 1997). Like the former Soviet republics that today are independent states, most current quasi-states in post-Soviet Eurasia were also formerly federal units of the Soviet Union, but on a lower level. The IC, however, has refused to accept status as a former autonomous unit on a lower level in the Soviet or the Yugoslav state as legitimate ground for independent statehood.

Aspiring state leaders also in other parts of the world are pointing to preexisting administrative or political borders to support claims to independent statehood. Somaliland has tried to persuade the world that it has the right to secede from Somalia, since it had been a separate British colony before 1960, and even enjoyed a brief moment - five days - of separate statehood before the two former colonies Somaliland and Somalia united (Pegg, 1998, 87). Arguments of this kind, however, are unlikely to carry the day.

If international recognition is extended to any of the world's current quasi-states this will not automatically turn them into functioning, 'normal' states. As pointed out above, many quasi-states have an economy and institutional structures that strongly 
resemble Jacksonian quasi-states or failed states. There is every reason to believe that if these states are granted international recognition simply as a reward for perseverance in the liberation struggle, or in sympathy with their sufferings at the hands of the challenger state, many of them will end up not as functioning or strong states, but instead as failed states or even 'shadow states'. Unless recognition is followed up by massive financial support and strict monitoring for an extended period of time, they may all too easily come to repeat the unfortunate experience of former European colonies in Africa.

\section{REABSORPTION INTO THE PARENT STATE}

Reabsorption happened to Katanga in 1965, Biafra in 1970, and Krajina in 1995. In the latter case, the Tudjman regime had quietly built up a strong army with offensive capacities and launched a surprise attack, Operation Storm. Western criticism of this operation was remarkably muted, in spite of the fact that it produced a fear-induced mass exodus of the local Serb population, similar in many ways to the flight of Palestinians from Israeli-controlled regions of Palestine in 1948. The subdued reaction to Operation Storm may encourage other parent states to attempt a military solution to their secession problem when they feel they are strong enough.

This suggests that two factors in particular will influence the likelihood of this scenario: the economic and political strength of the parent state and the reaction of the outside world. Should a parent state achieve both state consolidation and support from strong international actors they may attempt this outcome. 


\section{INCLUSION INTO THE PARENT STATE AS A SEPARATE ENTITY IN A}

\section{FEDERATED OR CONFEDERATE ARRANGEMENT}

A parent state that has used force to reabsorb a quasi-state may still accept a federated or confederate arrangement for the recovered territory. Having been (incompletely) reincorporated into the Russian state, Chechnia today enjoys the same republican status as other ethnically defined republics in the country, with the same formal rights and prerogatives under the Russian constitution. ${ }^{6}$

When reunification is the result of negotiated peaceful settlements a federal solution is an even more probable outcome. In negotiations between a parent state and a breakaway region this solution is often, in principle, accepted by both parties, but many observers suspect that one or both parties are only pretending to accept a federal arrangement. In the cases of DMR, Abkhazia, and Northern Cyprus, the breakaway regions have been accused of feigning support for a special-status-in-a-common-state solution as a smokescreen to create the false impression that they are engaged in real negotiations. While the separatist leaders regard the current unrecognized status of their state as inferior to full independence they see it as clearly preferable to a status as only an autonomous unit within another state. As Charles King has rhetorically asked, 'why be mayor of a small city if you can be president of a country? Why be lieutenant in somebody else's army if you can be a general in your own?' (King, 2001, $55)$.

Powerful criminal and black market elements in the quasi-state who benefit from the status quo actively obstruct negotiations from behind the scenes. It is therefore unlikely that movement in the direction of a negotiated federal solution will come 
from the quasi-state leaders. An impetus towards this outcome must come from the international community. Moreover, pressure must be put not only on the local parties but also on the external patron state.

In one instance in recent years the IC has dramatically stepped up its involvement in the efforts to resolve a quasi-state conflict. In the fall of 2003, the UN with direct involvement of its General Secretary Kofi Annan took an initiative for a voluntary unification between TRNC and the Greek-dominated part of the island. The Annan plan was linked to the EU enlargement process: a window of opportunity had opened up, it was hoped, as both Cyprus and Turkey eagerly wanted to join the European Union. Turkey reacted by forcing its client state TRNC into a more conciliatory position, but the plan nevertheless foundered in spring 2004 when it was voted down by the Greek Cypriots in a referendum. A serious problem with the plan was that it gave the Greek Cypriots a virtual veto right but few incentives to support it, since the Greek part of the island would be included into the EU even without reunification. The failure of the Annan plan was a major setback for international mediation in general and for UN involvement in particular and may discourage the IC from similar initiatives in the near future. Even so, it showed that external patron states, and through them also their client states, may be nudged towards compromise positions, given the right inducements.

In another case from recent years Republika Srpska was established as a separate ‘entity' of Bosnia-Herzegovina in the 1995 Dayton settlement as a result of active international engagement. In this case not the carrot but a huge stick - air bombingwas used to force the secessionists into pliability. Indicatively, in this case the 
solution was reached over the head of the secessionists themselves, by inviting only Slobodan Milosevic, the leader of the patron state, to the Dayton negotiations.

The Bosnian solution can hardly be called a success story, as least not yet. The Republika Srpska leadership obstructs as much cooperation and contact with the other entity of the Bosnian state, the Muslim-Croat federation, as they dare. Still, there are signs of a gradual normalization of the relationship between the two parts of the country. ${ }^{7}$

While the record is certainly mixed, a negotiated, federal settlement nevertheless is the solution that creates the lowest number of people who are so disgruntled that they will work actively to overturn it. In addition, the factors that militate against the alternative outcomes are clearly stronger. On balance, therefore, this compromise solution must be regarded as the most likely end to most unrecognized quasi-states.

\footnotetext{
${ }^{1}$ A Google search (May 2005) gave 120,000 hits for 'failed states' and only 6,200 for 'quasi-states'.

${ }^{2}$ King uses also the terms 'de facto states' and 'quasi-states' as synonymous with 'unrecognized states'.
} 
${ }^{3}$ Vladimir Kolossov and John O'Loughlin's term pseudo states is less felicitious as this designation implies a value assessment. As pseudos means 'a lie' in Greek their term 'pseudo states' seems to suggest that these entities ought to be condemned and obliterated. Perhaps some of them should, but this is a normative issue that this article will not address. See Kolossov and O’Loughlin, 1999.

${ }^{4}$ Some are willing to concede that the population of the breakaway area represents a regional or ethnic subgroup but not a distinct and separate nation.

${ }^{5}$ Author's interviews with DMR parliament deputy speaker Anna Volkova, and DMR 'foreign minister' Valery Litskai, in Tiraspol, in May 1992 and May 1995.

${ }^{6}$ In practice these rights have often been violated, for instance through centrally orchestrated fraudulent elections.

${ }^{7}$ Autor's interviews in Sarajevo and Banja Luka, May 2002 and November 2003. 


\section{BIBLIOGRAPHY}

Baev, Pavel K 1998. Russia's Policies in Secessionist Conflicts in Europe in the 1990s, The Norwegian Atlantic Committee, Security Policy Library no. 11-1998.

Beissinger, Mark R. and Crawford Young, eds, 2002. Beyond State Crisis? Postcolonial Africa and Post-Soviet Eurasia in Comparative Perspective, Washington, DC: Woodrow Wilson Center/John Hopkins University Press

Bowers, Stephen, 1994. 'The Dniester Republic-Further Insights', Jane's Intelligence Review Europe, December, pp. 562-64.

Bridge, Robert, 2004. 'Powell Visit: A Thaw in U.S.-Russian Relations?' The Moscow News, 9 July.

'Chechens Appeal to Council of Europe to End Russian 'Colonization,' 15 August 2001, online at http://tchetchenieparis.free.fr/text/Chechens-appeal-15-8-01.htm (accessed on 17 August 2004)

Cornell, Svante, 2003. 'Kvasistater i Eurasien', Nordisk Østforum, vol 17, no. 2, pp. 209-222.

de Waal, Thomas, 2003. Black Garden: Armenia and Azerbaijan through peace and war, New York: New York University press. 
Duplain, Julian, 'Chisinau's and Tiraspol's Faltering Quest of Accord', Transition, vol. 1, no. 19 , p.13.

Eide, Espen Barth 1999. “The Internal Security Challenge in Kosovo,” paper prepared for UNA-USA/IAI Conference on “Kosovo’s Final Status” Rome, 12-14

December,online at

http://www.unausa.org/newindex.asp?place=http://www.unausa.org/issues/kosovo/ro me/eide.asp, (accessed on 17 August 2004).

Fairbanks, Charles, 2002. 'Weak states and Private Armies,' in Beissinger og Young, Beyond State Crisis?, pp. 12-160.

Jackson, Robert, Quasi-states: Sovereignty, international relations and the third World (Cambridge: Cambridge University press, 1993)

Haynes, Jeff, 1994. 'Review of Robert Jackson Quasi-states: Sovereignty, international relations and the third World,' The Journal of commonwealth and comparative politics, vol. 32, no. 1, pp. 144-45.

Holmes, Kim R 2001. Understanding Putin's Foreign Policy Ph.D.

WebMemo \#22 July 12, 2001 I, The Heritage Foundation, http://www.heritage.org/Research/RussiaandEurasia/WM22.cfm (accessed on 17 August 2004)

King, ' Charles 2001. The Benefits of Ethnic War: Understanding Eurasia's 
Unrecognized States', World Politics, vol. 53, July, pp. 524-552.

Kolossov, Vladimir and John O’Loughlin, 1999. 'Pseudo-States as Harbingers of a New Geopolitics: The Example of the Transdniestr Moldovan Republic (TMR) in D. Newman, ed., Boundaries, Territory and Postmodernity. London: Frank Cass, pp. $151-176$

Kolstø, Pål, 2000. Political Construction Sites. Nation Building in Russia and the Post-Soviet States. Boulder, Colorado: Westview Press.

Kolstø, Pål, ed. 2002. National integration and violent conflict in post-Soviet societies: The cases of Estonia and Moldova. Boulder: Colorado: Rowman and Littlefield.

Kolstø, Pål and Andrei Malgin, 1998. 'The Transnistrian Republic: A Case of Politicized Regionalism', Nationalities Papers, vol. 26, March, pp. 103-128

Kolstø, Pål and Helge Blakkisrud eds, 2004. Nation-building and common values in Russia. Lanham: Rowman \& Littlefield.

Kniga pamiati zashchitnikov Pridnestrov'ia, 1995. Tiraspol: no publisher given.

Lapidus, Gail, 2002. 'Ethnicity and State-Building: Accommodating Ethnic Difference in Post-Soviet Eurasia," in Mark R. Beissinger and Crawford Young, eds, Beyond State Crisis? Postcolonial Africa and Post-Soviet Eurasia in Comparative 
Perspective. Washington, DC: Woodrow Wilson Center/John Hopkins University Press, pp. 323-358.

Lynch, Dov, 2002. 'Separatist states and post-Soviet conflicts', International Affairs, vol. 78 , no. 4 , pp. $831-848$.

Nagorno Karabagh: A White Paper, 1997. Yerevan: The Armenian Center for National and International Studies.

Neukirch, Claus, 2002. "The Influence of Interested Third and Disinterested Fourth Parties on The Conflicts in Estonia and Moldova," in Pål Kolstø, ed, National Integration and Violent Conflict in Post-Soviet Societies: The Cases of Estonia and Moldova. Boulder, Colorado: Rowman and Littlefield, pp. 233-248.

Nodia, Ghia, 'Putting the state back together in post-Soviet Georgia', in Beissinger og Young, Beyond State Crisis?, pp. 413-444.

The Orders and Medals of the NKR, The official site of the NKR Ministry of Foreign Affairs, http://nkr.am/eng/gov/atrib1.htm. (accessed on 17 August 2004)

Österud, Öyvind, 1997. 'The narrow gate: entry to the club of sovereign states', Review of International Studies, vol. 23, pp. 167-84.

Pascali, Umberto, 2001. 'KLA and Drugs: The "New Colombia of Europe" Grows in Balkans1, Executive Intelligence Review, June. 
Pegg, Scott, 1998. International Society and the De Facto state. Aldershot: Ashgate.

Reno, William, 2002. 'Mafiya Troubles, Warlord Crises', in Beissinger og Young, Beyond State Crisis?, pp. 105-127.

Socor, Vladimir, 1993. 'Dniester involvement in the Moscow Rebellion', $R F E / R L$ Research Report 2, no. 46, pp. 25-32.

Tishkov, Valery, 2004. Chechnya: life in a war-torn society. Berkeley: University of California press.

Troebst, Stefan, 2003. '”We Are Transnistrians!" (Post-)Soviet Identity Management in the Dniester Valley', Ab Imperio, vol. 1 (March).

Young, Crawford, 2002. 'After the Fall: state rehabilitation in Uganda', in Beissinger og Young, Beyond State Crisis?, pp. 445-464.

Welhengama, Gnanapala, 2000. Minorities' Claims: From Autonomy to Secession. International Law and state practice. Aldershot: Ashgate. 